\title{
INFORMATION SYSTEM IMPLEMENTATION AND AUDIT EFFICIENCY OF SELECTED INDIGENOUS PRACTICING FIRMS IN NORTH CENTRAL NIGERIA
}

\author{
Clement Olatunji Olaoye \\ Department of Accounting, Faculty of Management Sciences, Ekiti State University, \\ Iworoko road, Ado Ekiti, Ekiti State, Nigeria \\ Adebola Daniel Kolawole* \\ Department of Accounting, College of Social and Management Sciences, Afe Babalola \\ University, Afe Babalola way, Ado Ekiti, Ekiti State, Nigeria \\ *Corresponding Author
}

\begin{abstract}
This study examined the effect of information system on audit efficiency of selected indigenous practicing firms in North Central, Nigeria. The study employed a survey research design. Primary data were obtained and analysed using frequency distribution and multiple regression analysis. Findings from the study showed that the overall influence of information system on audit efficiency of selected indigenous practicing firms in North Central, Nigeria was significantly positive ( $F=766.445$, $p$ value $<0.05)$. Also, considering the influence of each component of information system implementation (ISI) on audit efficiency, the results showed that performance expectancy $(P E)(t=5.860, p=0.000<0.05)$ and effort expectancy $(E E)(t=16.932$, $p=0.000<0.05)$ had significant and positive influence on audit efficiency $(A E)$. The study concludes that ISI has positive influence on AE and recommends that indigenous practitioners with small sized audit firms should implement information system in their audit processes so as to enhance the effectiveness and efficiency of audit outcomes.
\end{abstract}

Key words: Audit efficiency, Information system, Indigenous practicing firms.

Cite this Article: Clement Olatunji Olaoye and Adebola Daniel Kolawole, Information System Implementation and Audit Efficiency of Selected Indigenous Practicing Firms in North Central Nigeria, International Journal of Management, 11(12), 2020, pp. 2451-2466.

http://iaeme.com/Home/issue/IJM?Volume=11\&Issue=12 


\section{INTRODUCTION}

Accounting practice has continued to evolve over the years in response to the development in information system. Information system has made accounting practice such as auditing easier and quicker to perform. Auditing which involves systematic process of obtaining and evaluating evidence of activities, events or transactions have now been revolutionized by the development of information technology (Abdul Rahman, Al-Nemrat \& Preston, 2014). Automated audit system is a way of checking the efficiency and accuracy of data procedures using computer devices. Applicability of computer auditing is based on a foundation of technical competence which forms an integral part of the overall audit activity. In the past, audit process was largely being performed using manual approach which consumed a lot of time but with the advent of information system, the process have been improved with higher speed, efficiency and quality. Automated audit system saves time and cost when forming and expressing professional opinion on financial information prepared by the management. Simpson (2018) noted that the role of automated audit can be extended to include the review of clerical procedures and the production of compliance based audit work programmes. This extension in the role of computer audit will eventually provide a wider systems audit service.

Automated audit system has become a major component of several audit firms in recent times. Without this, system auditors are limited in their ability to audit effectively and to provide a valuable service to the organization. Since business failures are occasioned by audit failures, there is need for audit process that will ensure quality of audit work done in an efficient manner considering the present day business complexities. Al-Hiyari, Al Said and Hattab (2019) noted that this is important because auditors are also faced with increased workloads and expectations from stakeholders regarding the scope and value of audit. Apparently, the advent of Information technology (IT) applications has brought about rapid changes to business processes in emerging economies like Nigeria (Ahmi et al., 2017). Most businesses have had to embrace the use of IT in order to improve their operations while ensuring efficient service delivery. With the adoption of IT tools, business activities are synchronized through an input-output process that facilitates timely reports of business and financial transactions. Consequently, audit procedures employed by audit firms have been equally affected by the new business process. The big 4 audit firms, foreign affiliated audit firms and other medium sized audit firms were not caught on aware with this change. This is because; they already have an established structure and technical capabilities that allows for a seamless adoption and implementation of relevant IT application tools. The small sized audit firms which are predominantly indigenous do not have the required structure to support adoption of automated system for their audit engagements. A major consideration is the associated cost outlay required to upgrade their audit procedures. This study is prompted by the question of how indigenous small sized audit firms respond to the rapid change in business processes occasioned by IT applications in order to meet stakeholders' expectation.

Despite the change in business model and the benefits that come with implementing information system in all audit engagements (Bierstaker et al., 2014), studies have shown that the extent to which indigenous small sized audit firms have adopted information system is still low (Curtis \& Payne, 2008; Dias \& Marques, 2018; Li et al., 2018). Some studies have been conducted on the adoption of computerized audit system (Mansour, 2016; Ebiumobowei, Ogbonna \& Enebraye, 2013; Venkatesh, Morris, Davis and Davis, 2003). However, previous studies have not addressed the extent to which information system (IS) affect audit efficiency of indigenous small sized practicing firms, hence, this study.

The consideration for north central region of Nigeria as the area of study was because of its peculiar settings. It is one of the six geo-political zones created by the federal government 
of Nigeria. Specifically the study focuses on selected indigenous practicing firms in the federal capital territory (FCT) which is the administrative territory of Nigerian federal government. Headquarters of ministries, agencies and parastatals are situated in the FCT. This explains why most businesses in Nigeria including audit firms have either their head offices or liaison offices in the region with lots of other businesses springing up regularly. Thus, the setting in this region provides high business prospects for all categories of audit firms. Although, the political and socio-cultural environment provides attractive latitude for business relationships with both existing and prospective clients, it equally has considerable implications on the decisions of auditors to use or not to use Information applications. Also, indigenous small sized audit firms are key players in the FCT. Moreover, the recent global pandemic caused by COVID 19 points to the timeliness of the study. In a bid to curtail the spread of the global pandemic in Nigeria, the FCT and Lagos state were locked down by the federal government while restrictions of movements were imposed in some other states. This necessitated the need for some businesses including audit firms to adopt automated approach in carrying out their operations. Hence, the study will prove useful to professional bodies regulating practice of accountancy in Nigeria. Findings from the study will contribute to existing literature regarding the influence of information technology applications on audit efficiency in emerging economies. The results of the study is expected to stimulate the integration of information system by partners and staff members of indigenous small sized practicing firms in Nigeria into their audit processes for value delivery to their clients in line with global best practices.

\section{LITERATURE REVIEW}

\subsection{Techniques of Automated Audit System}

The most common techniques of automated audit system are embedded in Computer Assisted Audit Techniques (CAATs). CAATS are computer programs designed to improve the efficiency and performance of the audit process as well as risk assessment procedures (Ciprian-Costel, 2014). Through the use of software, auditors can improve the quality of audit evidence (Sayana, 2003). By automating audit procedures, it removes subjectivity and bias in performing financial analysis and auditors save time (Al-Hiyari et al. (2019)). It also provide comprehensive analysis i.e. identification of both inherent and control risks; supplementation on trend analysis with data from multiple sources in order to assist in performing preliminary analytical reviews in risk-assessment process where its result drives overall audit approach (Vuchnich, 2008). These techniques include basic office software, spreadsheets and word processors, as well as advanced software programs including smart tools for business, able to perform statistical analysis, in parallel with the development of specialized audit software programs. Bierstaker et al. (2014) surveyed external auditors in U.S. and documented that the facilitating conditions and the performance expectancy are associated with increased acceptance and use of information technology.

\subsection{Information System (IS) and Audit Efficiency (AE)}

Information systems (IS) involve a variety of information technologies (IT) such as computers, software, databases, communication systems, the internet, mobile devices and much more, to perform specific tasks, interact with and inform various actors in different organizational or social contexts. Boell and Cecez-Kecmanovic (2015) described IS to involve a variety of IT used in performing specific tasks. The study noted that information system is concerned with how technology is appropriated to meet organisational needs. IS can be considered from various perspectives such as; social view, technology view, sociotechnical view, process view etc. This study considers the socio-technical view which not 
only emphasizes the significance of technology in the form of computer hardware, networks and applicable software but also humans and behavior rules within a business organisation. According to Boell and Cecez-Kecmanovicu (2015), IS phenomenon emerges when technological and social components interact. The socio-technical view was advanced by Unified Theory of Acceptance and Use of Technology (UTAUT) model to depict the interactions between technology and social component as captured by the four construct. Human requirement is a critical consideration in the implementation of information system in audit firms and not just the applications/devices. Additionally, Al-Hiyari et al., (2019) noted that various scholars from the disciplines of IS have stressed on the usefulness of using IT in business. The theories used in the IS studies has formed the foundation for investigating the influence of IS on audit efficiency. UTAUT model is one of the prominent theories. According to Mansour (2016), audit efficiency is when perceptions of the usefulness and productivity expected from using CAATs, will positively influence the intention to adopt it for use. Audit software enables auditors to facilitate audit exercise with the hope of promoting efficiency, effectiveness and quality of audit engagements. It is noted that the use of information technology in the audit process would improve its efficiency and effectiveness when properly employed. This study employed the four elements of Unified Theory of Acceptance and Use of Technology (UTAUT) model to operationalise information system implementation (ISI).

\subsection{Theoretical framework: Unified Theory of Acceptance and Use of Technology (UTAUT)}

This study was anchored on UTAUT theory which was propounded by Venkatesh et al. in 2003 after extensive review of eight (8) prominent models and theories with respect to individual acceptance of new information technologies. The reviewed models and theories are; theory of reasoned action (TRA), technology acceptance model (TAM), motivational model (MM), theory of planned behaviour (TPB), combined TAM and TPB (C-TAM-TPB), model of PC utilization (MPCU), innovation diffusion theory (IDT) and social cognitive theory (SCT).

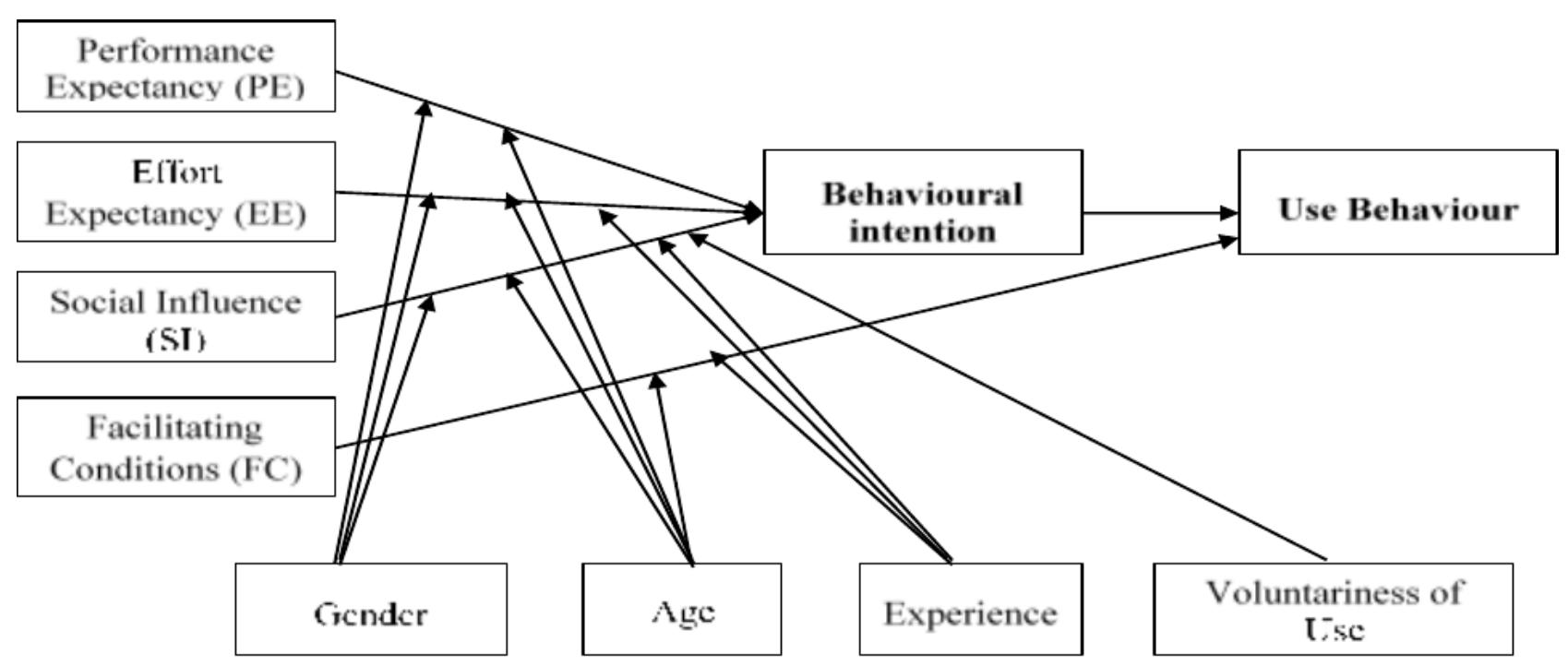

Figure 1 UTAUT Model

Source: Venkatesh et al. (2003) and Mansour (2016)

The core constructs of the previous models and theories were reviewed to provide basis for the establishment of unified model. UTUAT model identifies the key factors in acceptance 
of ICT as measured by behavioural intention to use the technology and actual usage. The unified model integrated all applicable elements across the reviewed eight models to develop four (4) core determinants of intention and usage of technologies namely; performance expectancy, effort expectancy, social influence and facilitating conditions. Venkatesh et al. 2003 assert that the first three of these constructs influence intentions to use, and the last one affects technology use. Oye et al. (2014) noted that the combination of the constructs and moderating factors modeled by UTAUT have resulted in increased the predictive efficiency over previous TAM mode rates.

\subsection{Hypotheses Development}

The UTAUT model was used to develop the conceptual framework for the study as shown in figure 2. The framework showed the relationship between audit efficiency (AE) and information system implementation (ISI). The ISI is composed of 2 predictor variables namely; performance expectancy (PE) and effort expectancy (EE) which were considered relevant to measure the relationship between the study variables based on the model constructs developed by Venkatesh et al. (2003), Ebimobowei et al (2013) and Mansour (2016)..The measurement scales for the study were developed based on the constructs adapted from UTAUT. The hypotheses were then formulated based on the conceptual framework. Audit efficiency is the dependent variable used in place of actual usage.

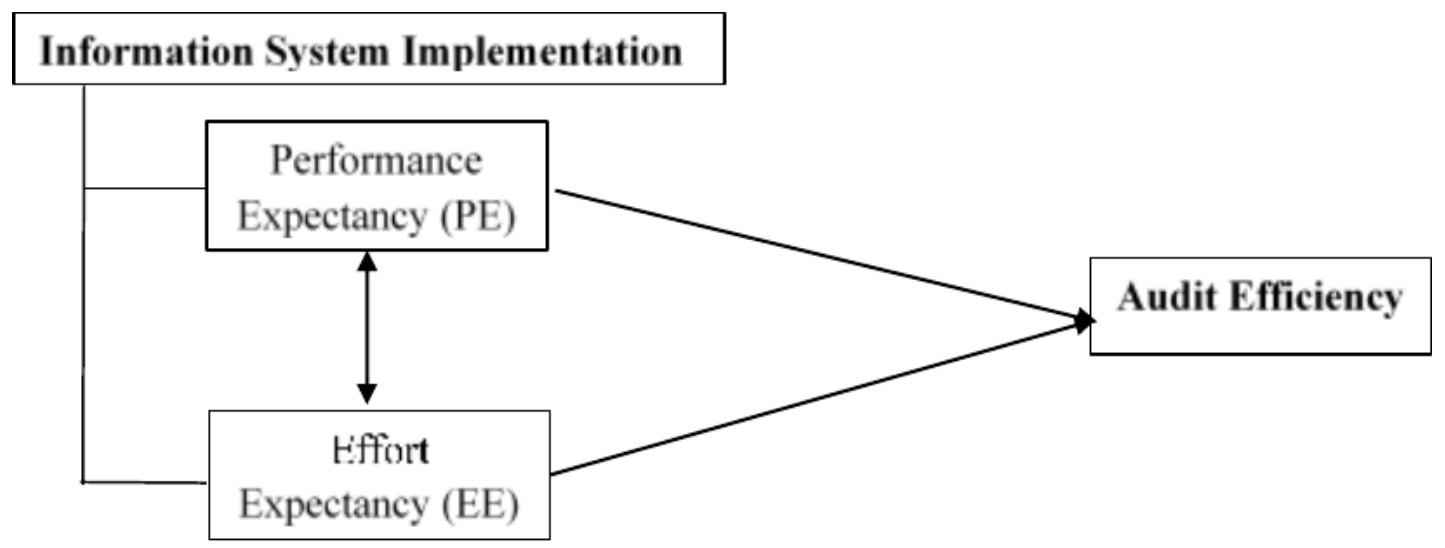

Figure 2 Conceptual framework for the research model (Adapted from Venkatesh et al (2003), Mahzan \&Lymer (2008) and Mansour (2016)

\subsection{Performance Expectancy (PE)}

The performance expectancy is one of the determinants in the unified model of Venkatesh et al (2003). It refers to the extent to which an individual believes that his or her use of information technology will enhance job performance. Findings from prior studies have shown that the use of technology tools could help to enhance efficiency and effectiveness of auditors' professional engagements, to perform other functions such as to test programme control, to gain better understanding of the client's information technology control, to facilitate risk assessment during planning processes (Mansour, 2016, Ebimobowei et al, 2013; Venkatech et al., 2003). PE was proven to be the strongest predictor of behavioral intention to use the technology as it shows a positive relationship. The null hypothesis is formulated thus:

$\mathbf{H}_{1}$ : Performance Expectancy does not have significant effect on Audit Efficiency 


\subsection{Effort Expectancy (EE)}

Effort expectancy element in the unified model of Venkatesh et al (2003) is described as the perceived ease of use. Venkatesh et al. (2003), stated that effort expectancy suggest a positive effect of perceived ease of use on behavioral intention indicating that there is a higher likelihood that auditors would adopt computer related audit procedures when they are easy to use and therefore do not have to undergo a difficult learning curve to make use of CAATTs. According to Mansour (2016), audit efficiency is when perceptions of the usefulness and productivity expected from using CAATs, will positively influence the intention to adopt it for use. Audit software enables auditors to facilitate audit exercise with the hope of promoting efficiency, effectiveness and quality of audit engagements. Thnaibat (2003) noted that the use of information technology in the audit process would improve its efficiency and effectiveness when properly employed. The null hypothesis is formulated thus:

$$
\mathbf{H}_{2} \text { : Effort Expectancy does not have significant effect on Audit Efficiency }
$$

\subsection{Indigenous Practicing Firms}

Indigenous practicing firms are firms of chartered accountants set up by nationals of a country and are accountable to their communities for increasing capacity while managing limited resources to ensure profitability. According to Adeoye (2015), audit firms in Nigeria have decried the poor implementation of the country's local content law. He noted that although, some international firms with indigenous partners and employees address themselves as local audit firms, many have argued that it is wrong to classify them as Nigerian firms simply because they have Nigerian workers and partners. Local content law was signed to create an opportunity for indigenous audit firms to grow as noted by Adeoye (2015). Although, the study conducted by Okot (2010) revealed that indigenous audit firms have remained small, poorly resourced and uncompetitive in light of proper management of intellectual capital. This study however adopted some selected indigenous small sized practicing firms because of the expected contribution of local content in stimulating the country's economic growth.

\subsection{Review of Empirical Studies}

Braun and Davis (2003) investigated the use of Computer-assisted audit tools and Techniques (CAATT) and satisfaction among states governmental auditors. The results revealed that auditors acknowledged the potential benefits of CAATs but demonstrated an inferior confidence in handling the audit software applications due to their technical capabilities and CAAT's technical problems. The study concluded that auditors IT skills can be enhanced through CAAT's training to boost their usage confidence. Mahzan and Lymer (2008) obtained integrated knowledge through quantitative and qualitative data into the factors that contributes to successful Computer Assisted Auditing Techniques (CAATs) adoption by internal auditors in the U.K. The study found out that the four dimensions proposed in their model of successful adoption (i.e. motivations for CAAT's adoption, best practices for implementation, challenges faced in the adoption process and methods for performance evaluation) were well supported by their findings as well, these factors by their own dimensions can be used as a guidance when discussing issues on CAAT's implementation. Curtis and Payne (2008) in their examination of the big 4 audit firms found out that communications of software usage by firm's partners have the ability to influence individual employee on new audit technology implementation. The auditors have a tendency to use new audit technology when they know that the firm's managing partner is supporting the technology usage in the firm. Furthermore, firm's longer-term financial plan and longer evaluation periods of audit technology also affect auditors' decision whether or not to use an audit technology. The study equally found out that individual characteristic such as risk-seeking auditors are more likely to implement new 
technology irrespective of firm budget pressure. On the other hand, low risk preference auditor would decide to use audit technology when there are high budget pressure.

Janvrin, Bierstaker and Lowe (2009) also noted that to increase Computer Assisted Auditing Techniques (CAATs) usage, audit firm management may want to develop training programmes and enhance their computer technical support to increase the auditor's degree of ease associated with using the techniques. Saygili (2010) revealed through a study on the use of specialized computer audit tools such as Computer Assisted Audit Tools and Techniques (CAAT) and Data Extracting and Analysis Systems (DEASs) and its implications for financial audit that it is possible to state that these tools greatly improve the efficiency and effectiveness of performance in a number of audit tests. DEASs helps improve confidence in decisions made due to its ability to scan and test all relevant information in its entirety without any omissions, elimination of human error in calculations and mechanical accuracy, minimize human errors in every procedure and test applied in addition to allowing for more comprehensive evaluation of internal control structure. Mahzan and Veerankutty (2011) investigated the IT practices of the public sector auditors in Malaysia by examining IT evaluation based on IT audit objectives, organisational characteristics, competency of auditor and usage of Computer Assisted Audit Tools and techniques (CAATTs). Primary data was obtained through the administration of survey questionnaire mailed to 400 public sector auditors. Findings from the study showed that application processing control and data integrity, privacy and security control were the most frequent evaluations performed by public sector auditors with CAATTs used most frequently as a problem solving aid. The study recommended that for a better understanding of client's computerized accounting system, the auditor should be well versed in the application of Computer Assisted Audit techniques (CAAT's) in their day to day operations.

Mansour (2016) examined the factors affecting the adoption of Computer Assisted Audit Techniques in Audit Process by Jordanian external auditors. The study use the Unified Theory of Acceptance and Use of Technology (UTAUT) to explore this lack of CAATs' usage in Jordan and try to find answer to what factors may affect their adoption and acceptance. Primary data was obtained through administration of survey questionnaire to 200 statutory external auditors. Findings from the study revealed that Jordanian external auditor's intention to adopt CAATs may be driven by both auditor's performance expectancy and firm's facilitating conditions issues but effort expectancy and social influence may not play such a major role. The study recommended that Jordanian audit firms can create a positive attitude amongst its auditors towards CAATs' usage by promoting CAATs benefits and usefulness, by decreasing efforts expectancy needed to use CAATs, and by further investing in management and technical infrastructure supporting CAATs. Studies conducted by Ebimobowei et al (2013), Tumi (2014); Alqatanani and Hezabr (2015), and Tarhini (2016)affirmed this findings. On the contrary, the findings of Sarfaraz (2017) from the study conducted on the application of UTAUT model on customers' intention to use mobile banking in Jordan reveals that it is not only performance expectancy that influences customers' intention to use but also effort expectancy while pointing out that social influence do not play a significant role. This is consistent with the findings of Palau-Saumell et al. (2019) on the adoption of mobile applications for restaurant searches and/or reservations (MARSR) by users using UTAUT 2 model but differs from the findings of Alraja (2016). Furthermore, the study conducted by AlHiyari et al. (2019) revealed that CAATs adoption is influenced by performance expectancy and effort expectancy.

The study conducted by Slade et al. (2015) using UTAUT model, revealed that performance expectancy, social influence, innovativeness, and perceived risk significantly influenced non-users' intentions to adopt remote mobile payments (RMPs), but effort 
expectancy did not. The studies by Khechine, Lakhal, Pascot and Bytha (2014) and Tarhini et al. (2016) also affirm this but Tey and Moses (2018) considers effort expectancy as strongest predictor of behavioural intention to use. While the study conducted by Adeyemi, Mohammed, Ogundeji and Tijani (2014) and Rosli, Yeow and Siew (2012) revealed that organization's management is crucial to adoption of CAATs, Al-Hiyari et al. (2019) investigated the factors that influence the use of CAATs by internal auditors in Jordan. The study employed UTAUT to examine the determinants of intention to adopt CAATs by internal auditors. Findings from the study showed that the actual use of CAATs by internal auditors remains unsatisfactory, and there is a paucity of evidence on the factors that may drive internal auditor's intention to accept and utilize CAATs in developing countries. Using 105 valid responses from internal auditors in Jordan, the results showed that CAATs adoption is influenced by performance expectancy as noted in Mansour (2016) and effort expectancy as noted by Alheety and Marei (2017).

\section{METHODOLOGY}

The study employed survey research design to elicit information from randomly selected respondents. Primary data was obtained through structured questionnaires designed by the researcher based on attitudinal variable of respondents. The validity of the instrument was determined through face validity. The data collected were analyzed using descriptive and inferential statistics. The study population consisted of audit staff members in the selected indigenous practicing firms in Abuja. Abuja was adopted to represent the North Central part of Nigeria as it is located at the centre of the country. The choice of north central was to examine the auditing approach of indigenous small sized practicing firms in area flooded with government and non-governmental activities but with minimal commercial activity. A sample of 200 staff members were randomly selected from six audit firms in Abuja municipal area council using a non-probabilistic sampling method. Audit firms were selected from Abuja municipal area council because it is the biggest local government area council by area and by population in the Federal Capital Territory (National Bureau of Statistics (NBS), 2011) and it is the home to the seat of the government of the Federal Republic of Nigeria. Out of two hundred (200) copies of questionnaire administered, one hundred and forty two (142) copies of questionnaire were returned. This represented $71 \%$ response rate but only one hundred and thirty (130) copies of questionnaire were valid for analysis representing 65\% response rate achieved for this study. The number of valid questionnaires for analysis was considered good. The demographic characteristics of respondents shows that males accounted for $53.1 \%$ and females accounted for $46.9 \%$. Also, 16\% were below 29 years old; $32.3 \%$ were between 30 and 39 years old; $44.6 \%$ were between 40 and 49 years old; and $6.2 \%$ were aged 50 years old and above. The majority of respondents were married (76.9\%); 88.5\% had first/postgraduate degrees, $77.7 \%$ had professional qualification and $50 \%$ of the respondents had work experience spanning more than 5years. The mix of respondents in terms of academic and professional qualifications, work experience as well as designations makes them appropriate targets for the study. 
Table 1 List of selected indigenous small sized audit firms in Abuja

\begin{tabular}{llll}
\hline Name of indigenous firms & DQ & QR & VQ \\
\hline Emeke Nwabuzor \& Co & 30 & 18 & 17 \\
Olamuyiwa Basiru \& Co & 30 & 15 & 15 \\
Olabisi Oladapo \& Co & 30 & 22 & 20 \\
Del Seven limited & 50 & 34 & 28 \\
John Edo Aiterebhe \& Co & 30 & 26 & 24 \\
Akande Akinsanya \& Co & 30 & 27 & 26 \\
Total & 200 & 142 & 130 \\
\hline
\end{tabular}

$\mathrm{DQ}=$ Distributed questionnaire, $\mathrm{QFR}=\mathrm{Questionnaire}$ Returned, $\mathrm{VQ}=$ Valid Questionnaire Source: Author's computation, 2020

\subsection{Model Specification}

The study adapted the model developed by Mansour (2016) which presented the functional relationship between the dependent and independent variables as follows:

$$
\mathrm{TIAU}=\beta_{0}+\beta_{1} \mathrm{PE}+\beta_{2} \mathrm{EE}+\beta_{3} \mathrm{FC}+\beta_{4} \mathrm{SI}+\varepsilon
$$

Where; TIAU $=$ Total Intention to CAAT's Adoption and Usage, PE $=$ Performance expectancy, $\mathrm{EE}=$ Effort expectancy, $\mathrm{FC}=$ Facilitating conditions, $\mathrm{SI}=$ Social influence, $\beta_{0}$ $\beta_{4}=$ Coefficients, $\varepsilon=$ Error term

In order to achieve the study objective, linear regression model was developed by modifying the model of Mansour (2016) to capture the effect of information system implementation on audit efficiency of selected indigenous audit firms in North Central, Nigeria. The modified model is presented in line with the study conceptual framework as follows:

$$
\begin{aligned}
& \mathrm{AE}=f(\mathrm{PE}, \mathrm{EE}) \quad 0<\beta<1 \\
& \mathrm{AE}=\beta_{0}+\beta_{1} \mathrm{PE}+\beta_{2} \mathrm{EE}+\varepsilon
\end{aligned}
$$

Where; $\mathrm{AE}=$ Audit Efficiency, $\mathrm{PE}=$ Performance expectancy, $\mathrm{EE}=$ Effort expectancy, $\beta_{0}-\beta_{3}=$ Coefficients, $\varepsilon=$ Error term

\subsection{A Priori Expectation}

The predictor variables; Performance expectation (PE), Effort Expectation (EE), Facilitating Conditions (FC) in the specified model are expected to be positively signed i.e.

$$
\beta_{0}<0 ; \quad \beta_{1}, \beta_{2},>0<1
$$


Information System Implementation and Audit Efficiency of Selected Indigenous Practicing Firms in North Central Nigeria

Table 2 Operationalisation of study variables

\begin{tabular}{|c|c|c|}
\hline Model constructs & Definition & Prior studies \\
\hline Performance Expectancy (PE) & $\begin{array}{l}\text { Performance expectancy is the degree to } \\
\text { which an individual believes that using the } \\
\text { system will help him or her to attain gains in } \\
\text { job performance. }\end{array}$ & $\begin{array}{l}\text { Venkatesh et al (2003), } \\
\text { Mahzan and Lymer (2008), } \\
\text { Ebimobowei et al (2013), } \\
\text { Mansour (2016) }\end{array}$ \\
\hline Effort Expectancy (EE) & $\begin{array}{l}\text { Effort expectancy is the degree of ease } \\
\text { associated with the use of the system. }\end{array}$ & $\begin{array}{l}\text { Venkatesh et al (2003), } \\
\text { Mahzan and Lymer (2008), } \\
\text { Ebimobowei et al (2013), } \\
\text { Mansour (2016) }\end{array}$ \\
\hline Audit Efficiency (AE) & $\begin{array}{l}\text { Audit efficiency is when perceptions of the } \\
\text { usefulness and productivity expected from } \\
\text { using CAATs, will positively influence the } \\
\text { intention to adopt it for use. }\end{array}$ & Mansour (2016) \\
\hline
\end{tabular}

Source: Venkatesh et al (2003), Ebimobowei et al (2013), Mahzan \&Lymer (2008) and Mansour (2016)

\section{DATA ANALYSIS AND PRESENTATION}

The study conducted normality test using one-sample Kolmogorov-Simirnov which shows that Audit Efficiency have normal distribution. Hence, the study proceeded to perform parametric tests. The linearity test conducted shows that there is a linear relationship between the dependent variable and each predictor variables. Also, the study performed reliability and sampling adequacy test prior to conducting factor analysis on the data. The reliability test was based on Cronbach's Alpha test while sampling adequacy test was based on Keiser-MeyerOlkin (KMO) measure of sampling adequacy and Bartlett's test of sphericity.

Table 3 Reliability test

\begin{tabular}{lll}
\hline Predictor Variables & Cronbach' s Alpha & No of Items \\
\hline Performance Expectancy & 0.744 & 3 \\
Effort Expectancy & 0.976 & 3 \\
\hline
\end{tabular}

Source: Authors' computation, 2020

The study considered Cronbach's Alpha coefficient of Correlation of 0.7 as the benchmark to confirm that the measurement scale used consistently reflect the scale they are measuring as noted by Field (2005). Table 4.1 above showed that all the predictor variables passed the reliability tests of 0.7 and above in line with general guideline of good reliability. The KMO and Bartlett's test of sphericity showed that all the study variables were statistically significant $(\mathrm{p}=0.000<0.05)$ indicating the appropriateness of running factor analysis. Also, a confirmatory factor analysis was conducted to check the statistical validity of the constructs.

\subsection{Factor Analysis}

The study adopted the approach of Mahzan and Lymer (2008) in conducting factor analysis on the study variables in order to determine the validity of the model construct. This study employed Principal Component Analysis (PCA) with Varimax rotation method to determine the most relevant question to be used for regression analysis. The principal component analysis was based on Kaiser's criterion of Eigen values greater than 1 as indicated by Field 
(2005). The study therefore adopts 1 as the cut off value for its factor loading extraction. This preliminary analysis resulted in selecting the most appropriate factors to be used for further analysis.

Table 4 Factor analysis of predictor variables

\begin{tabular}{|c|c|c|c|}
\hline Predictor variables & Questionnaire Items & Eigen values (Factor loading) & Variance (\%) \\
\hline \multirow[t]{3}{*}{$\begin{array}{l}\text { Performance } \\
\text { Expectancy (PE) }\end{array}$} & $\begin{array}{l}\text { Simplified audit } \\
\text { procedures }\end{array}$ & 1.996 & 66.54 \\
\hline & Audit supervision & 0.925 & \\
\hline & $\begin{array}{l}\text { Electronically stored } \\
\text { audit working papers }\end{array}$ & 0.079 & \\
\hline \multirow[t]{3}{*}{$\begin{array}{l}\text { Effort } \\
\text { (EE) }\end{array}$} & $\begin{array}{l}\text { Timely delivery of } \\
\text { audited accounts }\end{array}$ & 2.864 & 95.48 \\
\hline & $\begin{array}{l}\text { Appropriateness of } \\
\text { audit evidence }\end{array}$ & 0.101 & \\
\hline & $\begin{array}{l}\text { Arithmetic accuracy of } \\
\text { audited accounts }\end{array}$ & 0.035 & \\
\hline
\end{tabular}

Source: Field survey, 2020

Table 4 showed the factor analysis carried out on the questionnaire items used to depict each predictor variables. The results showed the factor loading for the measurement scales. Only the component with Eigen values of 1 and above was extracted as the most suitable question for each of the predictor variable. The extracted variable also showed the amount of variance in the predictor variables accounted for by the component. The simplified audit procedures accounted for $66.54 \%$ variance in the performance expectancy while Timely delivery of audited accounts indicated $95.48 \%$ variance in effort expectancy.

Table 5 Principal component analysis of explanatory variables

\begin{tabular}{|c|c|c|c|}
\hline Explanatory variables & Questionnaire Items & Eigen values & Extraction (Variance) \\
\hline Performance Expectancy (PE) & $\begin{array}{l}\text { Simplified } \\
\text { procedures }\end{array}$ & 1.996 & $1.996(66.54)$ \\
\hline Effort Expectancy (EE) & $\begin{array}{l}\text { Timely delivery of audited } \\
\text { accounts }\end{array}$ & 2.864 & $2.864(95.48)$ \\
\hline
\end{tabular}

Source: Authors' computation, 2020

Table 5 showed the most relevant component extracted from the analysis based on the extraction parameter of Eigen value above 1. The study considered the most highly loaded measurement scale. The components are; Simplified audit procedures $(\mathrm{EV}=1.996,66.54 \%)$ and Timely delivery of audited accounts $(\mathrm{EV}=2.864,95.48 \%)$. The extracted components were then used to carry out regression analysis. 
Information System Implementation and Audit Efficiency of Selected Indigenous Practicing Firms in North Central Nigeria

\subsection{Regression Analysis}

Table 6 Multiple regression analysis

\begin{tabular}{lrrrrrr}
\hline Model & R & $\mathbf{R}^{2}$ & Adjusted R $^{2}$ & F Change & Sig. F Change & Durbin-Watson \\
& & & & & \\
\hline 1 & $.961^{\mathrm{a}}$ & .923 & .922 & 766.445 & 0.000 & 1.119
\end{tabular}

a. Predictors: (Constant), Timely delivery of audited accounts, Simplified audit procedures

b. Dependent Variable: Audit efficiency

Source: Authors' computation, 2020

Table 6 presented the summary statistics for the regression analysis of showing the effect of information system implementation (ISI) on the audit efficiency of selected indigenous audit firms in North Central Nigeria. From table above, the multiple correlation coefficients $(\mathrm{R}=96.1 \%)$, represents the linear correlation between the observed and model-predicted values of the dependent variable. Its large value revealed a positive and strong relationship between the predictor variables and the dependent variable. From the table above, $\mathrm{R}^{2}$ is $92.3 \%$ and adjusted R Square is $92.2 \%$. The result of Durbin Watson stood at an acceptable level of 1.119. The results from the multiple regression analysis therefore showed that $92.3 \%$ variation in the dependent variable, audit efficiency (AE) is accounted for by the predictor variables, performance expectancy (PE) and effort expectancy (EE) when taking as a whole. Also, the overall influence of all performance expectancy (PE) and effort expectancy (EE) on audit efficiency (AE) of the selected indigenous audit firms in North Central, Nigeria is shown by $F$-statistics of 766.445 with $p$ value $=0.000<0.05$.

Table 7 Coefficient of predictor variables

\begin{tabular}{lcccrr}
\hline & B & Std. Error & T & Sig. & Correlation \\
\hline (Constant) & -.173 & .052 & -3.292 & .001 & \\
Performance Expectancy & .233 & .040 & 5.860 & .000 & 0.866 \\
Effort Expectancy & .715 & .042 & 16.932 & .000 & 0.832 \\
\hline
\end{tabular}

Source: Authors' computation, 2020

In addition, the study revealed that information system implementation (ISI) had positive influence on audit efficiency (AE) of the selected indigenous audit firms in North Central, Nigeria in terms of performance expectancy (PE) and effort expectancy (EE). Considering the influence of each component of information system implementation (ISI) on audit efficiency, the results showed that performance expectancy $(\mathrm{PE})(\mathrm{t}=5.860, \mathrm{p}=0.000<0.05)$ and effort expectancy $(\mathrm{EE})(\mathrm{t}=16.932, \mathrm{p}=0.000<0.05)$ had significant and positive influence on audit efficiency (AE) of the selected indigenous audit firms in North Central, Nigeria.

Incorporating the coefficient of the predictor variables, the multiple regression analysis can be written as follows:

$$
\mathrm{AE}=-0.173+0.233 \mathrm{PE}+0.715 \mathrm{EE}+\mu
$$

Equation 6, depicted that audit efficiency (AE) of the selected indigenous audit firms in North Central, Nigeria will be enhanced on average by 0.233 and 0.715 given a 1 unit 
increase in each of UTUAT variable construct that contributes to better performance expectancy and improved effort expectancy respectively.

\subsection{Descriptive Statistics}

In addition to the inferential statistic carried out, the study also conducted frequency distribution and percentage analysis of administered questionnaire on the predisposing factors affecting effective implementation of information system audit of selected indigenous practicing firms in North Central, Nigeria. The result showed that the use of information system in carrying out audit practice requires computer proficiency, recognized certification and technical know-how as affirmed by all the respondents (100\%). Also practitioners needs to ensure the applicability of the computerized audit system for its client as confirmed by all the respondents $(100 \%)$ but majority $(96.9 \%)$ of the respondents were not sure of the suitability of computerized audit system for companies with low volume of business transactions. All the respondents (100\%) agreed that audit software and other computer assisted audit techniques comes with high implementation cost. $60.8 \%$ of the respondents noted that indigenous small sized audit firms cannot afford audit software or other computer assisted audit techniques but $39.2 \%$ disagreed. In the view of some respondents $(71.6 \%)$, use of computerized audit procedures will result in increased audit fees which some of the clients may not be willing to pay. More so, most firm makes use of computerized audit system, the use of computerized audit software aids supervision of audit exercise, computerized audit system ensure increased efficiency in the performance of audit exercise, computerized audit software facilitates review of audit work within a record time, and there is effective security measures to ensure privacy and confidentiality of documents provided for audit. Furthermore, appropriate audit evidence as well as relevant information can be obtained electronically which facilitates the audit performance, there is high level of assurance regarding arithmetic accuracy of audited financial statements, audit procedures are simplified with the implementation of computerized audit system, and audit working papers can be prepared and stored electronically.

\subsection{Results and Discussion}

The study investigated the effect of information system implementation on audit efficiency of selected indigenous small sized audit firms in North Central, Nigeria using both descriptive and inferential statistical tools. Factors that affect implementation of information system for audit processes by indigenous small sized audit firms were also examined. Findings from the study showed that information system has positive and unique contribution to explaining variation in audit efficiency of by indigenous small sized audit firms $(\mathrm{F}=766.445$, $\mathrm{p}$-value $<$ 0.05). This is in line with the findings of Tumi (2014) and Ciprian-Costel (2014), which indicated fruitful influence of automated audit system on audit process. Furthermore, the study revealed that affordability, suitability of computerized audit systems for some clients, lack of technical know-how and high cost of implementing computerized audit were the factors affecting the implementation of information system for audit procedures by indigenous small sized audit firms. The result of the study showed that computerized audit system increase efficiency in the performance of audit exercise, facilitate review of audit work and effective security improves audit quality control. The findings also showed that reduction in the time of performing audit engagement, appropriate audit evidence, high level of assurance, audit procedure and preparation of audit working papers facilitate audit efficiency of selected indigenous small sized audit firms in North central, Nigeria. This is in line with the findings of Ahmi et al (2017), Mansour (2016), Ahmi \& Kent (2013) and Janvrin et al. (2009). Also, the study found that performance expectancy and effort expectancy had a positive association with audit efficiency of selected indigenous small sized audit firms in North central, Nigeria. 
This agrees with the findings of Alheety and Marei (2017) and Al-Hiyari (2019) but partly with the findings of Mansour (2016) and Tarhini (2017) on the significance of performance expectancy but disagreed on the note that effort expectancy is not significant.

\section{CONCLUSION AND RECOMMENDATIONS}

This study focuses on selected indigenous small sized audit firms in North central region of Nigeria. From the findings, it can be noted that the implementation of information system in terms of performance expectancy and effort expectancy will result in improved audit outcomes. The study thus concluded that information system had a positive association with audit efficiency and was statistically significant in explaining the audit efficiency of selected indigenous small sized audit firms in North central, Nigeria. The study recommended that indigenous practitioners with small sized audit firms needs to consider a shift from the manual audit approach to automated audit process for more audit engagements and improved service delivery. Practically, indigenous audit firms should invest more in training and development of staff members regarding IT related skills in order to enhance the effectiveness and efficiency of audit outcomes. The empirical contribution of this paper is that it specifically examines and extends the application of UTAUT model for indigenous small sized practicing firm in an emerging economy. The importance of the two constructs of UTAUT model employed, was highlighted in order to substantiate the need for up scaling in the audit process of indigenous firms in emerging economies like Nigeria. The limitation experienced in the study is that the sampled audit firms were taken from the central state in the north central geopolitical zone of Nigeria which might not be representative of what obtains in the other states due to peculiarity of socio-economic and political environment. Future research can be conducted on the relation between the application of information system and revenue generation of audit firms across a broader spectrum within the six geo-political zones in the country.

\section{REFERENCES}

[1] Abdul Rahman, L.B.A.A., Al-Nemrat, A. and Preston, D.S. (2014), "Sustainability in Information Systems Auditing", European Scientific Journal, Vol. 3, special edition, pp. 458 472

[2] Adeoye, T (2015), "Indigenous Audit Firms Cry Foul Over Lack of Government Patronage". The Guardian Business, available at: https://guardian.ng/business-services/indigenous-auditfirms-cry-foul-over-lack-of-govt-patronage

[3] Adeyemi, S., Mohammed, A., Ogundeji, M., \& Tijani, O. (2014). "Audit Technology Tools and Business Process Assurance: Assessment of Auditors' Perspective in Nigeria". Universal journal of Industrial and Business Management, 3(4), 93-102.

[4] Ahmi, A., Saidin, Z.S. and Abdullah, A. (2017), "Examining CAATTs Implementation by Internal Auditors in the Public Sector", Indian-Pacific Journal of Accounting and Finance, Vol. 1 No. 2, pp. 50-56

[5] Ahmi, A. and Kent, S. (2013), "The utilisation of generalized audit software (GAS) by external Auditors", Managerial Auditing Journal, Vol. 28 No. 2, pp. 88 - 113

[6] Alheety, S \& Marei, A. (2017). The impact of information technology on the development of audit process: Review of accepted theories of IT by the auditors, IJRDO-Journal of Business Management , 3 (4), 106-117

[7] Al-Hiyari, A., Al Said, N. and Hattab, E. (2019), "Factors That Influence the Use of Computer Assisted Audit Techniques (CAATs) By Internal Auditors in Jordan", Academy of Accounting and Financial Studies Journal. 
[8] Alraja, M. N. (2016). The effect of social influence and facilitating conditions on egovernment acceptance from the individual employees' perspective. Polish Journal of Management Studies, 14.

[9] Alqatanani, K. and Hezabr, A. (2015), "To what extent the auditors in the Kingdom of Bahrain recognize auditing strategies in the light of information technology and what is its impact on the audit? A field study", International Journal of Economics, Commerce and Management, Vol. 3 No. 5, pp 698-711.

[10] Bierstaker, J., Janvrin, D., \& Lowe, D. J. (2014). What factors influence auditors' use of computer-assisted audit techniques?. Advances in Accounting, 30(1), 67-74.

[11] Boell, S. K, and Cecez-Kecmanovic, D. (2015), "What is an information system?" in 2015 48th Hawaii International Conference on System Sciences, pp. 4959-4968, IEEE.

[12] Braun, R. L., \& Davis, H. E. (2003). Computer-assisted audit tools and techniques: analysis and perspectives. Managerial Auditing Journal, 18 (9), 725-731.

[13] Ciprian-Costel, M. (2014), "Arguments on using Computer-Assisted Audit Techniques (CAAT) and business intelligence to improve the work of the financial auditor", Management Strategies Journal, Vol. 26 No.4, pp. 212-220.

[14] Curtis, M. B., and Payne, E. A. (2008), “An examination of contextual factors and individual characteristics affecting technology implementation decisions in auditing. International Journal of Accounting Information Systems, Vol. 9 No. 2, pp. 104-121, available at: http://dx.doi.org/10.1016/j.accinf.2007.10.002

[15] Dias, C., \& Marques, R. P. (2018, June). The use of computer-assisted audit tools and techniques by Portuguese internal auditors. In 2018 13th Iberian Conference on Information Systems and Technologies (CISTI) (pp. 1-7). IEEE.

[16] Ebimobowei, A., Ogbonna, G. and Enebraye, Z. (2013), "Auditors' Usage of Computer Assisted Audit Techniques: Empirical Evidence from Nigeria", Research Journal of Applied sciences, Engineering and technology, Vol. 6 No. 3, pp. 187-195.

[17] Field, A. P., (2005), "Discovering Statistics using SPSS", Sage Publication, California

[18] Janvrin, D., Bierstaker, J. and Lowe, D. J. (2009), "An investigation of factors influencing the use of computer-related audit procedures". Journal of Information Systems, Vol. 23, pp. 97118, available at: http://dx.doi.org/10.2308/acch.2008.22.1.1

[19] Khechine, H., Lakhal, S., Pascot, D., \& Bytha, A. (2014). UTAUT model for blended learning: The role of gender and age in the intention to use webinars. Interdisciplinary Journal of E-Learning and Learning Objects, 10(1), 33-52.

[20] Li, H., Dai, J., Gershberg, T., \& Vasarhelyi, M. A. (2018). Understanding usage and value of audit analytics for internal auditors: An organizational approach. International Journal of Accounting Information Systems, 28, 59-76.

[21] Mansour, E. (2016), "Factors Affecting the Adoption of Computer Assisted Audit Techniques in Audit Process: Findings from Jordan". Business and Economic Research, Vol. 6 No.1, p.248, available at: http://dx.doi.org/10.5296/ber.v6i1.8996

[22] Mahzan, N. and Veerankutty, F. (2011), "IT auditing activities of public auditors in Malaysia", African Journal of Business Management, Vol. 5 No.5, 1551-1563.

[23] Mahzan, N., and Lymer, A. (2008), "Adoption of computer assisted audit tools and techniques (CAATs) by internal auditors: Current issues in the UK". Proceedings of the British Accounting Association Annual Conference, Blackpool, UK.

[24] NBS (2011), "National Bureau of Statistics", Annual Abstract of Statistics, available at: http://istmat.info/files/uploads/53129/annual_abstract_of_statistics_2011.pdf

[25] Okot, D. A. C. (2010), "Relationship between intellectual capital and business performance in indigenous audit firms in Uganda" (Doctoral dissertation, Makerere University). 
[26] Oye, N. D., Iahad, N. A., \& Rahim, N. A. (2014). The history of UTAUT model and its impact on ICT acceptance and usage by academicians. Education and Information Technologies, 19(1), 251-270.

[27] Palau-Saumell, R., Forgas-Coll, S., Sánchez-García, J., \& Robres, E. (2019). User acceptance of mobile apps for restaurants: An expanded and extended UTAUT-2. Sustainability, 11(4), 1210.

[28] Rosli, K.,, Yeow, P. and Siew, E. (2012), "Factors Influencing Audit Technology Acceptance by Audit Firms: A New I-TOE Adoption Framework", Journal of Accounting and Auditing: Research \& Practice, pp. 1-11, available at: http://dx.doi.org/10.5171/2012.876814

[29] Sarfaraz, J. (2017). Unified theory of acceptance and use of technology (UTAUT) modelmobile banking. Journal of Internet Banking and Commerce, 22(3), 1-20.

[30] Sayana, S. A. (2003), "Using CAATs to support IS audit", Information systems control journal, Vol. 1, pp. 21-23.

[31] Saygili, A.T. (2010), "Taking advantage of CAATTs during testing phase in financial audits: An empirical study of a food processing company in Turkey", Global Journal of Management and Business Research, Vol. 10, pp. 113-119.

[32] Simpson, B. (2018), “An Introduction to Computer Auditing”. London, available at: http://barclaysimpson.com (accessed12 December, 2019)

[33] Slade, E. L., Dwivedi, Y. K., Piercy, N. C., \& Williams, M. D. (2015). Modeling consumers' adoption intentions of remote mobile payments in the United Kingdom: extending UTAUT with innovativeness, risk, and trust. Psychology \& Marketing, 32(8), 860-873.

[34] Tarhini, A., El-Masri, M., Ali, M., \& Serrano, A. (2016). Extending the UTAUT model to understand the customers' acceptance and use of internet banking in Lebanon. Information Technology \& People.

[35] Tey, T. C. Y., \& Moses, P. (2018). UTAUT: Integrating achievement goals and learning styles for undergraduates' behavioural intention to use technology. EAI Endorsed Transactions on eLearning, 5(17).

[36] Thnaibat, A. (2003), "Use and Usefulness of Information Technology in the Audit Process in Jordan”, Derassat, Business Administration, University of Jordan, Vol. 30, pp. 253-268.

[37] Tumi, A. (2014), "An investigative study into the perceived factors precluding auditors from using CAATs and CA", International Journal of Advanced Research in Business, Vol. 1 No. 3, 2-11.

[38] Venkatesh, V., Morris, M. G., Davis,G. B., and Davis, F. D. (2003), "User Acceptance of Information Technology: Toward a Unified View", MIS Quarterly, Vol. 27, pp. 425-478, available at: http://www.jstor.org/stable/30036540

[39] Vuchnich, A. (2008), "Using CAATTs in Preliminary Analytical Review", available at: https://boards.fool.com/using-caatts-in-preliminary-analytical-review-26351047.aspx?

sort=postdate (accessed 7 December, 2019) 